\title{
Immune complexes (IC) down-regulate the basal and interferon- $\gamma$-induced expression of MHC Class II on human monocytes
}

\author{
P. BARRIONUEVO, M. BEIGIER-BOMPADRE, S. DE LA BARRERA, M. F. ALVES-ROSA, G. FERNANDEZ, \\ M. S. PALERMO \& M. A. ISTURIZ CONICET, División Inmunología, Instituto de Investigaciones Hematológicas, Academia
} Nacional de Medicina, Buenos Aires, Argentina

(Accepted for publication 8 May 2001)

\begin{abstract}
SUMMARY
The interaction of $\mathrm{Fc}$ receptors for $\mathrm{IgG}(\mathrm{Fc} \gamma \mathrm{Rs})$ on monocytes/macrophages with immune complexes (IC) triggers regulatory and effector functions. Previous studies have shown that $\mathrm{Fc} \gamma \mathrm{R}-\mathrm{IC}$ interactions inhibit the IFN- $\gamma$-induced expression of MHC class II in murine macrophages. However, the mechanism(s) responsible for these effects have not been elucidated. In addition, whether this ICdependent effect also occurs in human cells is not known. Taking into account the fact that IC and IFN- $\gamma$ are frequently found in infections and autoimmune disorders, together with the crucial role MHC class II molecules play in the regulation of immune response, we explored the effect and mechanism of ICinduced MHC class II down-regulation in human peripheral blood mononuclear cells (PBMC). This effect was studied either in the presence or absence of IFN- $\gamma$. We demonstrate that IC exert a drastic inhibition of basal and IFN- $\gamma$-induced expression of MHC class II on human monocytes. This effect was mediated through the interaction of IC with both Fc $\gamma$ RI and Fc $\gamma$ RII. Moreover, similar results were obtained using supernatants from IC-treated PBMC. The IC-induced down-regulation of MHC class II is abrogated by pepstatin and phosphoramidon, supporting the role of aspartic protease(s) and metalloprotease(s) in this process. In parallel with MHC class II expression, antigen presentation was markedly inhibited in the presence of IC.
\end{abstract}

Keywords IC IFN- $\gamma$ monocyte MHC class II

\section{INTRODUCTION}

The formation of circulating immune complexes (IC) is the physiological consequence of antibody responses to different antigens, including microorganisms [1], or the result of autoimmune disorders such as rheumatoid arthritis, vasculitis or lupus erythematosus [2]. These IC can interact with the Fc receptors for $\mathrm{IgG}(\mathrm{Fc} \gamma \mathrm{Rs})$ present on cells of the immune system, triggering a variety of regulatory and effector functions [3-8].

Three different types of Fc $\gamma$ Rs (Fc $\gamma$ RI, Fc $\gamma$ RII and Fc $\gamma$ RIII) are widely and heterogeneously distributed on different cells including $\mathrm{B}$ and $\mathrm{T}$ lymphocytes, neutrophils, and monocytes/ macrophages [9-11]. Monocytes, which constitutively express Fc $\gamma$ RI and Fc $\gamma$ RII, are known as one of the most important cells at sites of chronic inflammation. Thus, the interaction of Fc $\gamma$ Rs on monocytes/macrophages and IC, their natural ligands, enables these cells to induce the secretion of different substances such as enzymes, oxygen species, prostaglandins, leukotrienes [3-5], a variety of cytokines, such as interleukin- $1 \beta$ (IL-1 $\beta$ ), IL-6, IL-10,

Correspondence: Paula Barrionuevo, Academia Nacional de Medicina, Pacheco de Melo 3081, (1425) Buenos Aires, Argentina.

E-mail: isturiz@hematologia.anm.edu.ar tumour necrosis factor alpha (TNF- $\alpha)$ [6,7], and also to increase intracellular cAMP levels [8].

Interferon- $\gamma$ (IFN- $\gamma$ ) has been largely recognized as capable of inducing an increase in the expression of Fc $\gamma \mathrm{RI}$ and class II molecules from the major histocompatibility complex (MHC class II) in monocytes/macrophages [12-17]. Since monocytes are intimately involved in immune mechanisms, the consequences of the Fc $\gamma \mathrm{R}-\mathrm{IC}$ interaction on these cells has been investigated in the last two decades. Previous studies by Schreiber [18] and Virgin [12] have shown that the preincubation of murine macrophages with IC inhibits either the ability of IFN- $\gamma$ to induce tumoricidal activity or the enhancement of the expression of MHC class II. However, the mechanism(s) responsible for these effects have not been elucidated. In addition, whether this ICdependent effect also occurs in human cells is not known.

Taking into account the fact that IC are frequently found in infections and autoimmune disorders, in conjunction with the known pleiotropic effects induced by IFN- $\gamma$ and the crucial importance of MHC class II in the regulation of the immune response, studies concerning the interactive mechanisms between these aspects are needed in order to obtain a comprehensive view of the interplay, and for any eventual therapeutic intervention. In this report, we explored the effect and possible mechanism 
of IC-induced MHC class II down-regulation in human peripheral blood mononuclear cells (PBMC), either in the presence or absence of IFN- $\gamma$.

\section{MATERIALS AND METHODS}

\section{Reagents}

Ficoll 400, tissue culture medium (RPMI 1640), human recombinant IFN- $\gamma$, chromatographically purified ovalbumin (OA), phenyl methyl sulphonyl fluoride (PMSF), pepstatin, phosphoramidon and leupeptin were all purchased from Sigma Chemical Co., St Louis, MO, USA. Fluorescein isothiocyanate (FITC)-labelled anti-HLA-DR, phycoerythrin (PE)-labelled antiCD14 monoclonal antibodies (MoAb), affinity purified $\mathrm{F}\left(\mathrm{ab}^{\prime}\right)_{2}$ fragment goat antimouse $\operatorname{IgG}(\mathrm{H}+\mathrm{L})$, and mouse $\mathrm{IgG} 1$ and IgG2a control isotype antibodies were obtained from Immunotech, Marseille, France. MoAb anti-CD64 (anti-Fc $\gamma$ RI) was purchased from Calbiochem, San Diego, CA, USA. MoAb IV.3 (anti-Fc $\gamma$ RII) was from Medarex, West Lebanon, NH, USA. $\left[{ }^{3} \mathrm{H}\right]-$ Thymidine came from New England Nuclear, Boston, MA, USA. The Mycobacterium tuberculosis strain H37Rv was grown on $7 \mathrm{H} 11$ agar (Difco Laboratories, Detroit, USA) at $37^{\circ} \mathrm{C}$ in $5 \% \mathrm{CO}_{2}$ air at mid-log phase. M. tuberculosis were harvested, sonicated to break up the clumps, washed three times by centrifugation and resuspended in phosphate buffer saline (PBS) free of pyrogen at a concentration of $1 \times 10^{8}$ bacteria/ml. Bacteria were killed by heating at $85^{\circ} \mathrm{C}$ for $20 \mathrm{~min}$ and then aliquoted and stored at $-20^{\circ} \mathrm{C}$ until their use.

\section{Immune complexes and heat-aggregated $\operatorname{Ig} G$}

Immune complexes (IC) were prepared using rabbit IgG antiovalbumin (OA), isolated from heat-inactivated serum by affinity chromatography. Precipitating ovalbumin (OA)-rabbit IgG antiOA immune complexes were prepared at three-fold antigen excess, based on equivalence points determined by quantitative precipitation curves. Antigen and antibodies were incubated for $30 \mathrm{~min}$ at $37^{\circ} \mathrm{C}$ and $1 \mathrm{~h}$ at $4^{\circ} \mathrm{C}$. After this period, IC were centrifuged at $10000 \mathrm{~g}$ for $5 \mathrm{~min}$, the supernatant was discarded and precipitating IC were suspended at $1 \mathrm{mg}$ antibody/ml. The soluble human heat-aggregated $\mathrm{IgG}$ (agg-IgG) was prepared by heating purified human $\mathrm{IgG}$ at a concentration of $5 \mathrm{mg} / \mathrm{ml}$ for $12 \mathrm{~min}$ at $63^{\circ} \mathrm{C}$. Then, the heat aggregated human IgG was centrifuged at $10000 \mathrm{~g}$ for $5 \mathrm{~min}$ and the precipitate was discarded. The supernatant containing soluble agg-IgG was diluted with medium to a concentration of $1 \mathrm{mg} / \mathrm{ml}$.

\section{Preparation of human mononuclear cells}

Fresh human blood was obtained by venipuncture from healthy adult volunteers and collected into citrate/dextrose/adenine. Blood was diluted 1:2 with saline, layered on a Ficoll-Hypaque cushion, and centrifuged at $400 \mathrm{~g}$ for $25 \mathrm{~min}$ as described previously [19]. Peripheral blood mononuclear cells (PBMC) were collected, washed and resuspended in RPMI $10 \%$ heatinactivated $\left(56^{\circ} \mathrm{C}, 30 \mathrm{~min}\right)$ fetal calf serum and $50 \mu \mathrm{g} / \mathrm{ml}$ gentamycin. Viability of mononuclear cells was always greater than $98 \%$ as measured by the trypan blue exclusion test.

\section{Flow cytometry}

After different treatments, $1 \times 10^{6}$ mononuclear cells were washed and incubated with different MoAbs. The cells were washed, resuspended in ISOFLOW and flow cytometry was performed using a FACS Analyser (Becton-Dickinson Immunocytometry System, San Jose, CA, USA). The results were expressed as the percentage of median of fluorescence intensity (MFI) of CD14 positive cells $\left(\mathrm{CD} 14^{+}\right)$of non-treated groups (controls). Background fluorescence intensity was obtained using mouse IgG1 or IgG2a isotype matched control antibodies.

\section{Supernatant assay}

PBMC $\left(4 \times 10^{6}\right.$ cells $\left./ \mathrm{ml}\right)$ were treated with IC $(100 \mu \mathrm{g} / \mathrm{ml})$ or RPMI at $37^{\circ} \mathrm{C}$ in a $5 \% \mathrm{CO}_{2}$ atmosphere for $18 \mathrm{~h}$. After this period, supernatants $(1 \mathrm{ml})$ were collected, spun down to remove cellular debris $(10 \mathrm{~min}$ at $6000 \mathrm{rpm})$ and stored at $-70^{\circ} \mathrm{C}$ until their use, unless stated otherwise.

\section{Proliferation assay}

PBMC at a concentration of $1 \times 10^{6}$ cells $/ \mathrm{ml}$ were left to adhere in 96-well flat-bottomed plates for $2 \mathrm{~h}$ at $37^{\circ} \mathrm{C}$. Then, the nonadherent cells were removed and the adherent population was incubated with either IC $(100 \mu \mathrm{g} / \mathrm{ml})$, IFN- $\gamma(240 \mathrm{U} / \mathrm{ml})$ or both at $37^{\circ} \mathrm{C}, 5 \% \mathrm{CO}_{2}$ for $24 \mathrm{~h}$. After this period, the cells were washed and incubated with non-adherent PBMC $\left(1 \times 10^{6}\right.$ cells $\left./ \mathrm{ml}\right)$ in the absence (controls) or presence of $M$. tuberculosis $\left(1 \times 10^{6}\right.$ bacteria/ $\mathrm{ml}$ ). Cells were incubated for 5 days at $37^{\circ} \mathrm{C}, 5 \% \mathrm{CO}_{2}$, pulsed with $\left[{ }^{3} \mathrm{H}\right]$-thymidine for $18 \mathrm{~h}$ and harvested as described previously [20]. The index of $\left[{ }^{3} \mathrm{H}\right]$-thymidine incorporation was calculated for each treatment as: $\mathrm{cpm}$ in presence of $M$. tuberculosis/cpm in absence of $M$. tuberculosis.

\section{Statistical analysis}

All experiments were repeated at least five times and a representative one is shown unless otherwise stated. Statistical significance of results was calculated using the non-parametric Mann-Whitney test (two-tailed).

\section{RESULTS}

IC down-regulate the basal and IFN- $\gamma$-induced expression of MHC class II antigens on human monocytes

Preincubation of PBMC with precipitating ovalbumin (OA)-rabbit IgG anti-OA immune complexes exerted a drastic inhibition of MHC class II up-regulation induced by IFN- $\gamma$ on human monocytes. The IC treatment also reduced the basal expression

Table 1. The effect of IC on MHC class II down-regulation is reversible

\begin{tabular}{lcr}
\hline & & \\
& Treatment & \\
agg-IgG & IFN- $\gamma$ & $\%$ MFI of control \\
\hline- & & 100 \\
+ & - & 84 \\
- & - & 285 \\
+ & + & 248 \\
\hline
\end{tabular}

PBMC $\left(1 \times 10^{6}\right.$ cells $\left./ \mathrm{ml}\right)$ were incubated with medium or soluble agg-IgG $(200 \mu \mathrm{g} / \mathrm{ml})$ during $24 \mathrm{~h}$ at $37^{\circ} \mathrm{C}$. Then, the cells were washed and incubated with medium or IFN- $\gamma(240 \mathrm{U} / \mathrm{ml})$ during additional $24 \mathrm{~h}$ as indicated. After this period, PBMC were stained with anti-HLA-DR and anti-CD14 antibodies. The table shows a representative experiment of $n=3$. Data are expressed as percentage MFI of control cells and correspond to the $\mathrm{CD} 14^{+}$population of PBMC. 
of MHC class II (Fig. 1). Similar results were achieved using soluble human heat-aggregated $\operatorname{IgG}(\mathrm{agg}-\mathrm{IgG})$ instead of IC (data not shown).

In order to discount a possible non-specific effect such as steric hindrance induced by IC on the subsequent binding of FITClabelled MoAb to class II antigens, $1 \times 10^{6} \mathrm{PBMC}$ were incubated with IFN- $\gamma$ for $24 \mathrm{~h}$ in order to increase MHC class II expression, and then incubated with IC in a crushed ice bath (to arrest metabolic activity) for 3 additional hours. Immediately after this period, flow cytometry was performed. The percentage MFI of both IFN- $\gamma$ and IFN- $\gamma /$ IC-treated cells were similar and not significantly different (\% MFI of control, IFN- $\gamma$ : 183\%; IFN- $\gamma+$ IC: $215 \%$; a
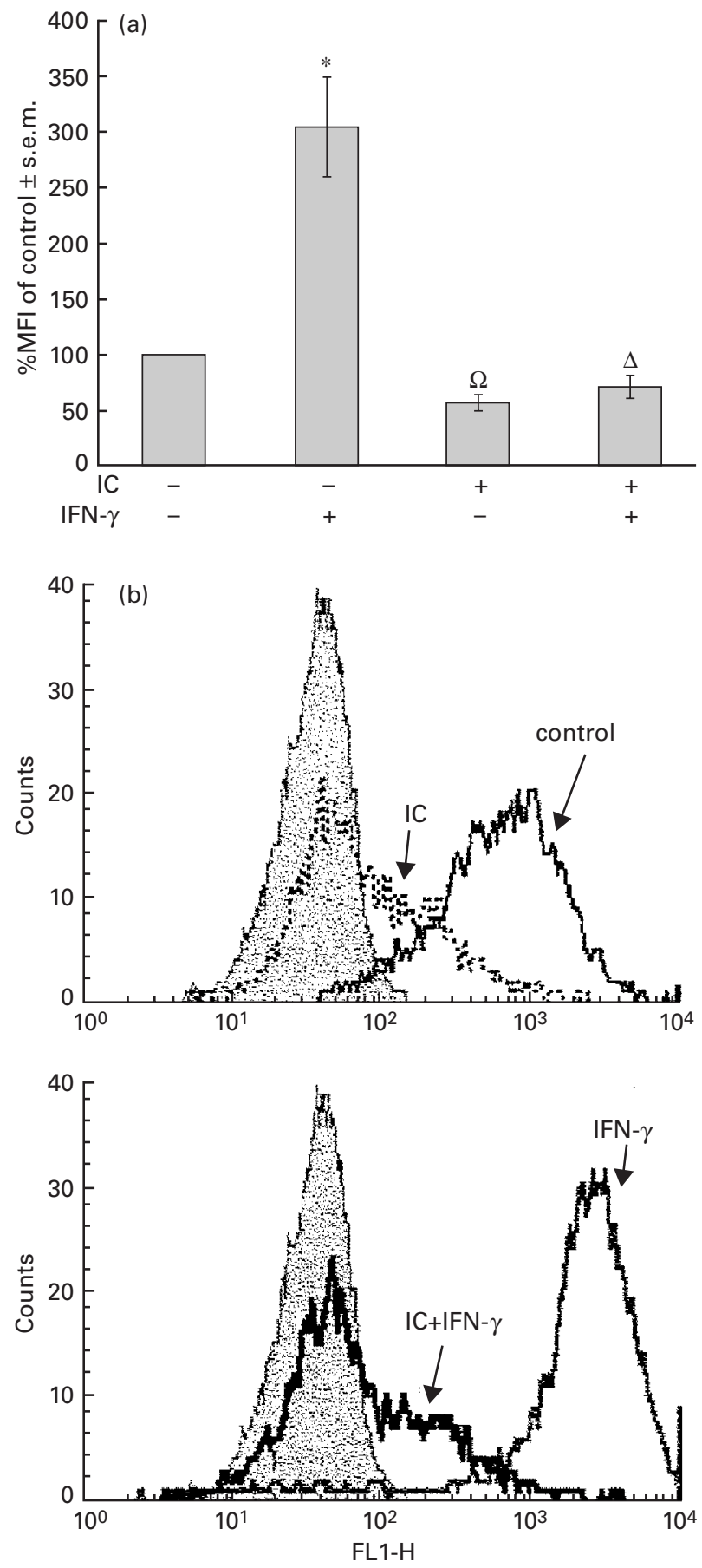

representative experiment of $n=3$ ), indicating that the low values of MHC class II expression observed in Fig. 1 were due to effective IC-induced down-regulation.

\section{IC-dependent MHC class II down-regulation is mediated by Fc $\gamma R I$ and Fc $\gamma$ RII}

Although $\mathrm{Fc} \gamma \mathrm{RI}$ and $\mathrm{Fc} \gamma \mathrm{RII}$ are constitutively expressed on human monocytes [9,11], only Fc $\gamma$ RI is up-regulated by IFN- $\gamma$ treatment (data not shown) [21]. Thus, it was important to determine if the ICinduced MHC class II down-regulation was mediated through the interaction of IC with overexpressed Fc $\gamma$ RI, Fc $\gamma$ RII, or both receptors. For this purpose, PBMC were incubated with anti-Fc $\gamma \mathrm{RI}$ and/or anti-Fc $\gamma$ RII monoclonal antibodies, followed by incubation with a $\mathrm{F}\left(\mathrm{ab}^{\prime}\right)_{2}$ anti-mouse IgG to induce the $\mathrm{Fc} \gamma \mathrm{Rs}$ cross-linking necessary to induce the down-regulation of class II antigens. Finally, the cells were treated with IFN- $\gamma$ and $24 \mathrm{~h}$ later MHC class II expression was determined. As shown in Fig. 2, both monoclonal antibodies were able to inhibit the MHC class II up-regulation induced by IFN- $\gamma$. Furthermore, the combination of both antibodies did not induce additional inhibition.

\section{IC inhibit MHC class II expression in a reversible and dose-dependent manner}

As shown in Fig. 3, the IC-dependent down-regulation of MHC class II is a dose-dependent effect for both basal and IFN- $\gamma$ induced expression. Another important issue for a physiological process was to determine whether this effect was reversible. For this purpose, PBMC were exposed for $24 \mathrm{~h}$ to soluble human heataggregated IgG (agg-IgG). Then, the cells were exhaustively washed to eliminate the excess of agg-IgG and incubated with IFN- $\gamma$ for an additional $24 \mathrm{~h}$. As shown in Table 1, the expression of MHC class II on agg-IgG/washed/IFN- $\gamma$-treated cells reached similar levels to those on naive cells treated only with IFN- $\gamma$ indicating that the agg-IgG-induced down-regulation of $\mathrm{MHC}$ class II is reversible. A similar effect was observed in the recovery of MHC class II expression on naive cells treated only with agg$\mathrm{IgG}$ and washed. However, when agg-IgG was maintained throughout the experiment, a significantly lower amount of MHC class II was expressed (\% MFI of control, agg-IgG $48 \mathrm{~h}$ : $43 \%$ ), indicating that the presence of IC is necessary for prolonged MHC class II down-regulation.

\section{Effect of IC after IFN- $\gamma$ treatment}

In the above-mentioned experiments, IC were added to PBMC

Fig. 1. Effect of IC on basal and IFN- $\gamma$-induced MHC class II expression. PBMC $\left(1 \times 10^{6}\right.$ cells $\left./ \mathrm{ml}\right)$ were incubated with medium (control) or IC $(100 \mu \mathrm{g} / \mathrm{ml})$. After $1 \mathrm{~h}$ at $37^{\circ} \mathrm{C}$, the cells were incubated with IFN-g (240 $\mathrm{U} / \mathrm{ml}$ ) for $24 \mathrm{~h}$ as indicated in the figure. After this period, PBMC were stained with anti-HLA-DR and anti-CD14 antibodies and evaluated by flow cytometry. (a) Data are expressed as the percentage of median of fluorescence intensity $(\% \mathrm{MFI}) \pm$ s.e.m. of control cells and correspond to the $\mathrm{CD} 14^{+}$population of PBMC. Statistical significance was calculated using Mann-Whitney test, two-tailed, $n=17 . * P<0.0001$ significantly different from control. $\Omega P<0.0001$ significantly different from control and IFN- $\gamma$-treated cells. $\Delta P<0.01$ significantly different from control and $P<0.0001$ significantly different from IFN- $\gamma$-treated cells. (b) The histograms represent the $\mathrm{CD} 14^{+}$population of PBMC and correspond to one representative experiment of $n=17$. Background fluorescence intensity (filled peak) was obtained using control isotype antibodies. $x$-axis: fluorescence intensity (arbitrary units); $y$-axis: cell number. 


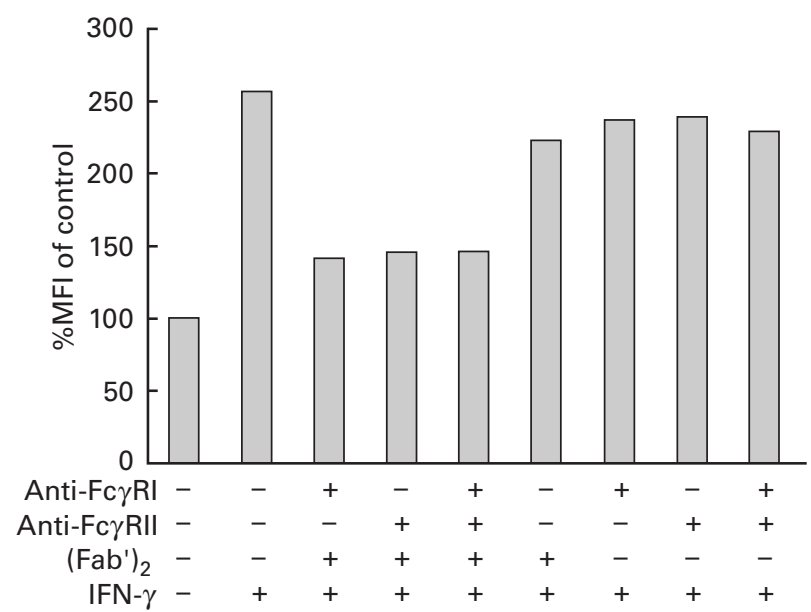

Fig. 2. Effect of anti-Fc $\gamma \mathrm{RI}$ and/or anti-Fc $\gamma \mathrm{RII}$ on IFN- $\gamma$-induced MHC class II expression. PBMC $\left(1 \times 10^{6}\right.$ cells $\left./ \mathrm{ml}\right)$ were incubated with either medium or anti-Fc $\gamma \mathrm{RI}(5 \mu \mathrm{g} / \mathrm{ml})$ and/or anti-Fc $\gamma \mathrm{RII}(5 \mu \mathrm{g} / \mathrm{ml})$ for $1 \mathrm{~h}$ at $4^{\circ} \mathrm{C}$. Then, the cells were washed and incubated with medium or $\left(\mathrm{Fab}^{\prime}\right)_{2}$ anti-mouse $\operatorname{IgG}(10 \mu \mathrm{g} / \mathrm{ml})$ for $1 \mathrm{~h}$ at $37^{\circ} \mathrm{C}$. After this period, the cells were washed and incubated with medium or IFN- $\gamma(240 \mathrm{U} / \mathrm{ml})$ for $24 \mathrm{~h}$ and stained with anti-HLA-DR and anti-CD14 antibodies. Data are expressed as percentage MFI of control cells and correspond to the CD14 population of PBMC. The inhibition of class II antigen by IC $(100 \mu \mathrm{g} / \mathrm{ml})$ in the same experimental conditions was $63 \%$. The figure shows one representative experiment of $n=5$.

before IFN- $\gamma$. The next experiment was designed to investigate whether IC would also be capable of inducing the down-regulation of class II antigens on cells that have already been treated with IFN- $\gamma$. Thus, PBMC were incubated with IFN- $\gamma($ time $=0 \mathrm{~h})$. At $20 \mathrm{~h}$ post-IFN- $\gamma$ treatment, IC were added to the cells. The expression of MHC class II was analysed at $24 \mathrm{~h}$ by flow cytometry. As shown in Fig. 4, IC were effective at downregulating $\mathrm{MHC}$ class II expression in both cases. These results suggest strongly that this is a post-translational effect. Furthermore, a time-dependent effect was observed (data not shown).

\section{Effect of supernatants from PBMC stimulated with IC on MHC} class II expression

Taking into account the results shown in Fig. 4 and considering that IC can induce secretory events in monocytes, we investigated the role of supernatants obtained from IC-stimulated PBMC during the MHC class II down-regulatory process. For this purpose, PBMC were incubated with medium or IC for $18 \mathrm{~h}$. After this period, the supernatants were collected and added to IFN- $\gamma$ stimulated PBMC. The results shown in Fig. 5 indicate that supernatants from IC-treated cells were able to reduce the IFN- $\gamma$ induced expression of MHC class II. These data show clearly the role of PBMC-released product(s) on MHC class II downregulation. Supernatants obtained from precipitating IC incubated with medium alone for $18 \mathrm{~h}$ (controls) were devoid of effects (\% MFI of control \pm s.e.m.: $198 \pm 2$ ), discount the presence of IC in these supernatants.

Effect of proteases inhibitors on MHC class II down-regulation With the purpose of elucidating some characteristics of the product(s) responsible for MHC class II down-regulation,

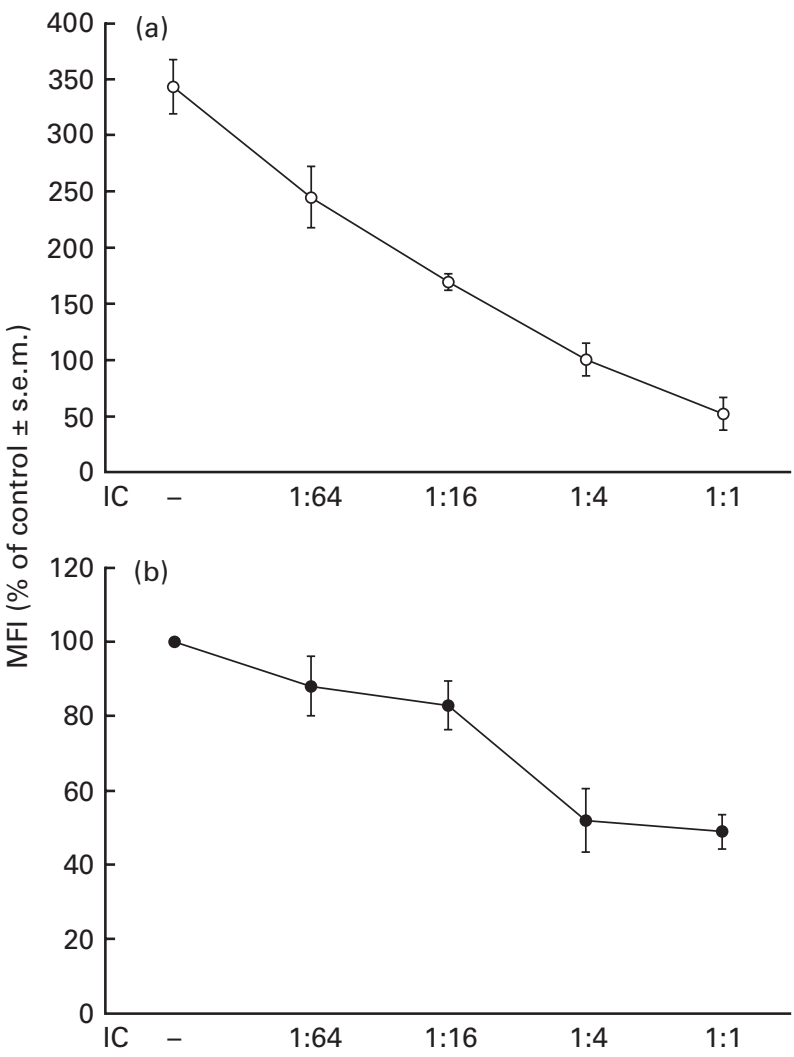

Fig. 3. Effect of different amounts of IC on basal and IFN- $\gamma$-induced MHC class II expression. PBMC $\left(1 \times 10^{6}\right.$ cells $\left./ \mathrm{ml}\right)$ were incubated with medium (control) or different ratios of IC as indicated in the figure (1:1 corresponds to the concentration $100 \mu \mathrm{g} / \mathrm{ml})$. After $1 \mathrm{~h}$ at $37^{\circ} \mathrm{C}$, the cells were incubated with (a) IFN- $\gamma(240 \mathrm{U} / \mathrm{ml})$ or (b) medium for $24 \mathrm{~h}$. After this period, PBMC were stained with anti-HLA-DR and anti-CD14 antibodies and evaluated by flow cytometry. Data are expressed as percentage MFI \pm s.e.m. of control cells and correspond to the CD14 population of PBMC, $n=3$.

Table 2. Effect of proteases inhibitors on the IFN- $\gamma$-induced MHC class II expression

\begin{tabular}{lll}
\hline \multicolumn{2}{c}{ Treatment } & \\
\cline { 1 - 2 } Supernatant & \multicolumn{1}{c}{ Inhibitor } & $\%$ MFI of control \pm s.e.m. \\
\hline- & - & $258 \cdot 3 \pm 39 \cdot 40$ \\
+ & - & $163 \cdot 3 \pm 27 \cdot 82^{*}$ \\
+ & PMSF $(2 \mathrm{mM})$ & $178 \cdot 3 \pm 28 \cdot 59^{*}$ \\
+ & Pepstatin $(1 \mathrm{mM})$ & $249 \cdot 7 \pm 13 \cdot 38$ \\
+ & Phosphoramidon $(10 \mu \mathrm{M})$ & $236 \cdot 0 \pm 19 \cdot 40$ \\
+ & Leupeptin $(50 \mu \mathrm{M})$ & $190 \cdot 5 \pm 10 \cdot 40^{*}$ \\
& & \\
\hline
\end{tabular}

PBMC $\left(1 \times 10^{6}\right.$ cells $\left./ \mathrm{ml}\right)$ were incubated with IFN- $\gamma(240 \mathrm{U} / \mathrm{ml})$ during $24 \mathrm{~h}$. Then, the cells were exposed to supernatants from IC-treated PBMC, with or without protease inhibitors, during $3 \mathrm{~h}$. After this period, PBMC were stained with anti-HLA-DR and anti-CD14 antibodies. Data are expressed as percentage MFI \pm s.e.m. of control cells and correspond to the $\mathrm{CD} 14^{+}$population of PBMC. Statistical significance was calculated using the Mann-Whitney test, two-tailed; $n=5 . * P<0.05$ significantly different from IFN- $\gamma$-treated cells. 


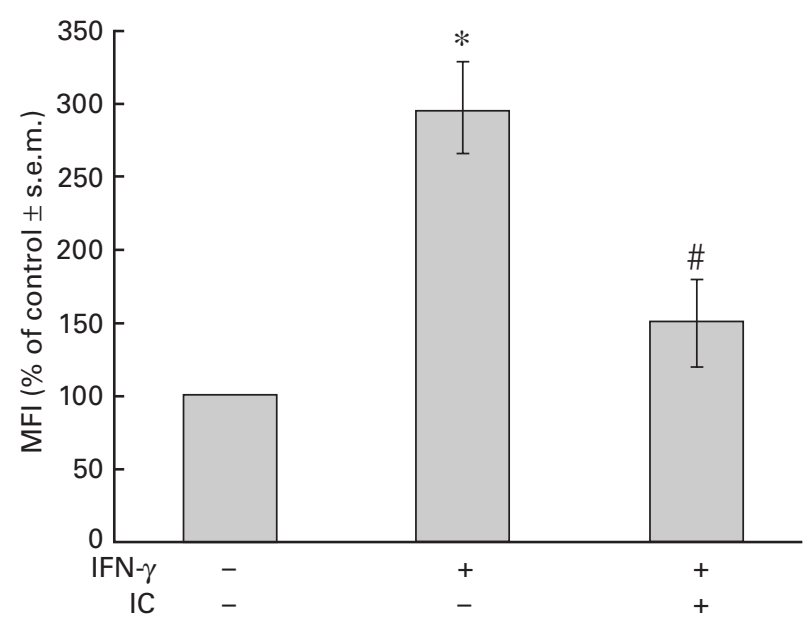

Fig. 4. Effect of IC after IFN- $\gamma$ treatment. PBMC $\left(1 \times 10^{6}\right.$ cells $)$ were incubated with medium or IFN- $\gamma(240 \mathrm{U} / \mathrm{ml})$ for $20 \mathrm{~h}$. Then, IC $(100 \mu \mathrm{g} /$ $\mathrm{ml}$ ) were added and incubated for a further $4 \mathrm{~h}$. After this period, the cells were stained with anti-HLA-DR and anti-CD14 antibodies. Data are expressed as percentage MFI \pm s.e.m. of control cells and correspond to the $\mathrm{CD} 14^{+}$population of PBMC. The percentage MFI of IFN- $\gamma$-treated cells at 24 or $20 \mathrm{~h}$ were similar and not significantly different $(\%$ MFI \pm s.e.m. of control, IFN- $\gamma 24$ h: $297 \pm 43$; IFN- $\gamma 20$ h: $258 \pm 32$; $n=6$ ). Statistical significance was calculated using Mann-Whitney test, two-tailed; $n=6$. $* P<0.002$ significantly different from control. $\# P<0.02$ significantly different from IFN- $\gamma$-treated cells.

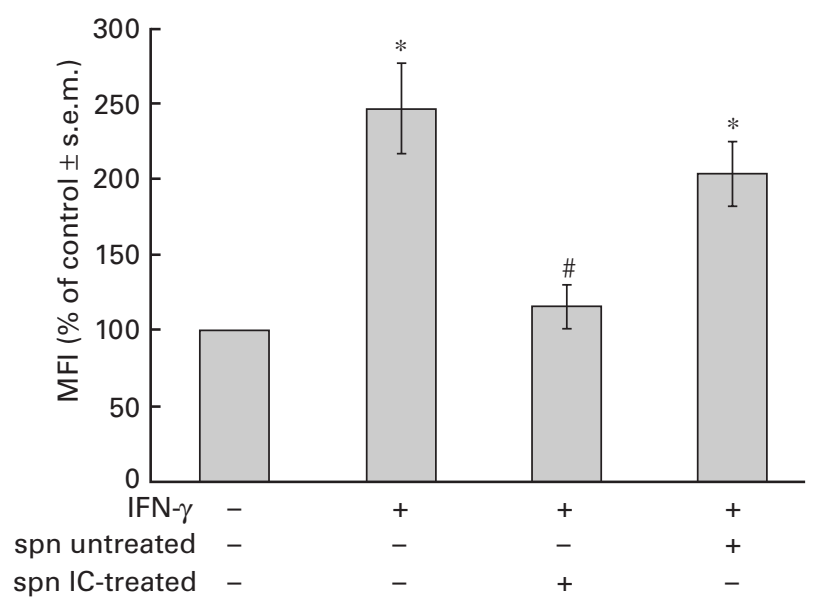

Fig. 5. Effect of supernatants (spn) from PBMC stimulated with IC on IFN- $\gamma$-induced MHC class II expression. PBMC $\left(1 \times 10^{6}\right.$ cells $\left./ \mathrm{ml}\right)$ were incubated with IFN- $\gamma(240 \mathrm{U} / \mathrm{ml})$ for $24 \mathrm{~h}$. Then, the cells were exposed to spn from untreated or IC-treated PBMC for $3 \mathrm{~h}$. After this period, PBMC were stained with anti-HLA-DR and anti-CD14 antibodies. Spn from IC incubated with medium alone for $18 \mathrm{~h}$ were obtained by centrifugation and were devoid of any effects on IFN- $\gamma$-induced MHC class II expression. Data are expressed as percentage MFI \pm s.e.m. of control cells and correspond to the $\mathrm{CD} 14^{+}$population of PBMC. Statistical significance was calculated using Mann-Whitney test, two-tailed; $n=5$. ${ }^{*} P<0.008$ significantly different from control. $\# P<0.02$ significantly different from IFN- $\gamma$-treated cells and $P<0.03$ significantly different from spn untreated PBMC-treated cells.

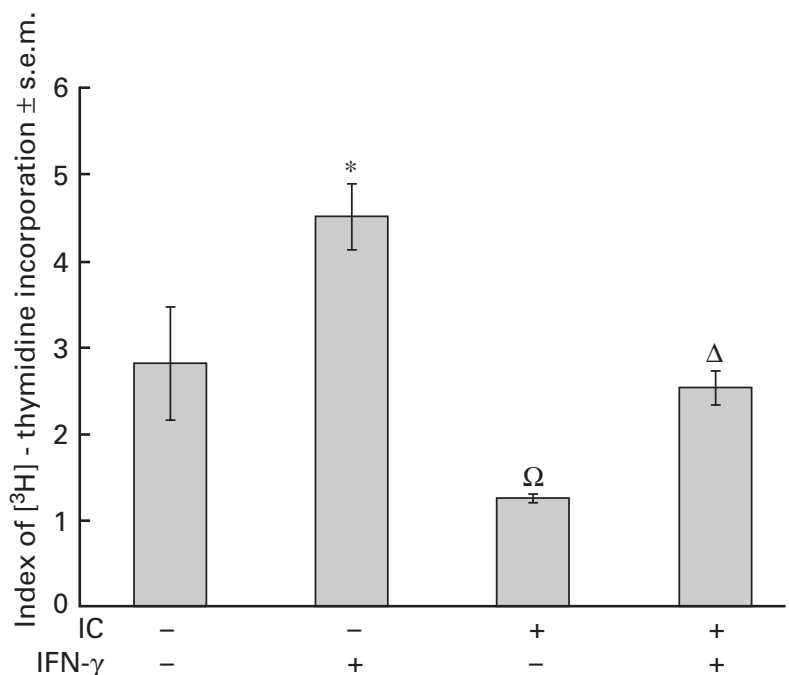

Fig. 6. Effect of IC on antigen presentation. Adherent PBMC were obtained as indicated in Materials and methods and were incubated with medium or IC $(100 \mu \mathrm{g} / \mathrm{ml})$. After $1 \mathrm{~h}$, the cells were incubated with IFN- $\gamma(240 \mathrm{U} / \mathrm{ml})$ for $24 \mathrm{~h}$. Then, the cells were washed and incubated with non-adherent PBMC in the absence or presence of Mycobacterium tuberculosis. The index of $\left[{ }^{3} \mathrm{H}\right]$-thymidine incorporation was calculated as indicated in Materials and methods. Statistical significance was calculated using the Mann-Whitney test, two-tailed; $n=5$. $* P<0.05$ significantly different from control. $\Omega P<0.03$ significantly different from control and IFN- $\gamma$-treated cells. $\Delta P<0.03$ significantly different from IFN- $\gamma$-treated cells.

IFN- $\gamma$-stimulated PBMC were incubated with supernatants from IC-stimulated monocytes treated with different protease inhibitors. These inhibitors included PMSF, capable of inhibiting all serin proteases with a trypsin-like specificity (e.g. trypsin, thrombin, plasmin, kallikrein) [22], pepstatin, which is an inhibitor of aspartic proteases (e.g. cathepsin D, renin, pepsin) [23], phosphoramidon, a metalloprotease inhibitor [24] and the cysteine protease inhibitor leupeptin [25].

The results shown in Table 2 indicate that the down-regulation of IFN- $\gamma$-induced expression of MHC class II is abrogated by pepstatin and phosphoramidon, supporting the role of aspartic protease(s) and metalloprotease(s) in this process.

In a previous report [12], prostaglandins have been shown to be involved in the regulation of MHC class II expression in mice. However, the treatment of human PBMC with $0.35 \mu \mathrm{g} / \mathrm{ml}(1 \mu \mathrm{M})$ or $1.75 \mu \mathrm{g} / \mathrm{ml}(5 \mu \mathrm{M})$ indomethacin did not modify the IC-effect, suggesting that prostanoids were not involved in the IC-induced MHC class II down-regulation ( $n=6$, data not shown). Other factors such as IL-10 have also been shown to be involved in the regulation of IC-induced major susceptibility to Listeria monocytogenes [26]. However, adding IC to IFN- $\gamma$-treated or untreated cells in the presence of anti-IL-10 $(5-10 \mu \mathrm{g} / \mathrm{ml})$ did not modify the expression of MHC class II ( $n=5$, data not shown).

\section{Effect of IC on antigen presentation}

It is well known that MHC class II molecules are central for antigen presentation [27]. Consequently, in light of the experiments shown above, we investigated whether the observed ICinduced MHC class II down-regulation correlated with the functional activity of monocytes. For this purpose, we evaluated the capacity for antigen presentation of untreated and IC-treated PBMC using a M. tuberculosis proliferation assay [20]. As shown 
in Fig. 6, in parallel with MHC class II expression, antigen presentation was markedly inhibited in the presence of IC.

\section{DISCUSSION}

The observation that IC inhibit IFN- $\gamma$-dependent expression of Ia antigens was initially reported by Hanaumi et al. [14] and Virgin et al. [12] in mouse macrophages, although the mechanisms underlying this effect were not elucidated.

In this report we found that IC down-regulate both basal and IFN- $\gamma$-induced expression of MHC class II antigens on human monocytes in a dose-dependent manner, and that the presence of IC is necessary for a sustained effect. In fact, when soluble aggIgG are eliminated after initial PBMC exposure, the cells express basal levels of MHC class II antigens (Table 1). These results indicate that the effect of IC is reversible and they also discount any deleterious effects exerted by IC on human monocytes.

Monocytes constitutively express two types of $\mathrm{Fc} \gamma \mathrm{Rs}$ ( $\mathrm{Fc} \gamma \mathrm{RI}$ and $\mathrm{Fc} \gamma \mathrm{RII}$ ) and transduce signals through both of them [9]. Since IFN- $\gamma$ induces the up-regulation of Fc $\gamma$ RI but not Fc $\gamma$ RII, it was important to know whether the IC-induced MHC class II downregulation was induced only through the interaction of IC with Fc $\gamma$ RI. However, the results shown in Fig. 2, where specific MoAbs to Fc $\gamma$ RI and Fc $\gamma$ RII were used as agonists instead of IC, demonstrate clearly that both Fc $\gamma$ Rs are committed to MHC class II down-regulation.

Previous reports have shown that IC inhibit IFN- $\gamma$-induced signals by preventing tyrosine phosphorylation of the transcription factor STAT1, through the inhibition of the tyrosine kinases JAK1 and JAK2 [28]. This mechanism, although carefully studied for IFN- $\gamma$-induced expression of Fc $\gamma$ RI, has also been proposed for the inhibition of MHC class I and II genes, which are similarly dependent on STAT1 activation [28]. Although our results obtained with PBMC treated with IC and later with IFN- $\gamma$ (Figs 1 and 2) might be in agreement with this interpretation, evidence confirming this possibility is lacking. On the other hand, the diminished expression of MHC class II induced by IC on naive or IFN- $\gamma$-pretreated PBMC (Figs 1 and 4) is incompatible with the inhibition of early IFN- $\gamma$ signalling pathways (JAKs/STAT1) induced by IC [28]. In fact, our results demonstrate that IC induce the elimination of MHC class II molecules already expressed on the surface of monocytes, indicating a different mechanism of down-regulation. The cause of this effect could be attributed to either a delay in the turnover of these molecules, to an ICdependent accelerated shedding of MHC class II antigens in monocytes or it could be due to the cleavage of molecules from the cell surface.

Several membrane molecules are cleaved from the surface of leucocytes and other cells by endogenous cellular enzymes, thereby releasing their soluble fragments into the extracellular medium [29,30]. Hence, we investigated the role of supernatants obtained from IC-stimulated PBMC in MHC class II downregulation. Our results demonstrate that these supernatants were able to significantly reduce the expression of MHC class II molecules on monocytes. Other molecules capable of inducing MHC class II down-regulation such as prostaglandins [12] or IL10 [26] were discounted since neither indomethacin nor anti-IL-10 $\mathrm{MoAb}$ altered the IC effects. Alterations in the number and/or affinity of IFN- $\gamma$ receptors induced by IC were not studied here because they have been explored exhaustively and discounted by others $[28,31]$.
Two types of mechanisms have been described for the physiological enzymatic cleavage of leucocyte membrane molecules. One of these requires an interaction between receptors and their specific agonists, such as IL-3 [32] and CD27 [33] ligand, leading to cleavage of the receptors themselves. Another pathway is initiated by agonists that stimulate cells via receptors that are different from the molecules to be cleaved [29]. Our results are clearly in agreement with the latter scenario since IC downregulation operates via the secretion of products that later modulate MHC class II expression. Nevertheless, we cannot discard the involvement of other proposed mechanisms for MHC class II down-regulation such as IC-inhibition of JAKs/STAT1 pathways [28]. However, this latter mechanism could only be involved in those experiments where preincubation of IC with PBMC was performed before their exposure to IFN- $\gamma$. In fact, MHC class II down-regulation on cells that have already expressed MHC class II molecules, cannot be dependent on JAKs/STATs effects.

With the purpose of investigating the mechanism responsible for MHC class II down-regulation, supernatants from ICstimulated monocytes were treated with inhibitors of serine, aspartic, cysteine, and metalloproteases [22-25]. Down-regulation of MHC class II was abrogated only by pepstatin and phosphoramidon, supporting the role of aspartic and metalloprotease(s) in this process (Table 2). In relation to this, it has been demonstrated recently that MHC class I antigens are also cleaved by metalloproteases [34].

Wherever possible, a correlation between phenotypic marker and function should be investigated. Therefore, an important MHC class II-dependent function such as antigen presentation was assayed to assure the functionality of the cells after the exposure to different treatments. The results obtained in Fig. 6 resemble a typical antigen-driven lymphocyte proliferation, providing clear evidence that monocytes were indeed under IC regulatory effects.

Since the expression of MHC class II constitutes a central event in the control of the immune system and inflammatory reactions, the regulation of these molecules by IC may be crucial for eventual therapeutical intervention. Whether the IC-dependent release of active molecules described in this paper represents a regulatory mechanism of class II antigens in vivo is currently under investigation in our laboratory using a model of localized inflammation.

\section{ACKNOWLEDGEMENTS}

Blood samples were kindly provided by the Servicio de Hemoterapia, CEMIC, Buenos Aires, Argentina. We thank Sonia Gomez for critical reading of the manuscript, Fundación de la Hemofilia for the FACScan Flow Cytometer, and Sergio Fridman, Viviana Pressiani and Antonio Fernández for technical assistance. This work was supported by grants from Consejo Nacional de Investigaciones Científicas y Técnicas (CONICET), Agencia Nacional de Promoción Científica y Tecnológica, Fundación Antorchas and Fundación Alberto J. Roemmers (Buenos Aires, Argentina).

\section{REFERENCES}

1 Schifferli JA, Taylor RP. Physiological and pathological aspects of circulating immune complexes. Kidney Int 1989; 35:993-1003.

2 Mannik M. Pathophysiology of circulating immune complexes. Arthritis Rheum 1982; 25:783-7.

3 Kasai S, Akaike T, Kunimoto T, Nitta K. Superoxide anion production 
from mouse peritoneal macrophages stimulated with surface-bound $\mathrm{IgG}$ and immune complexes: adsorption characteristics of $\mathrm{IgG}$ in relationship to biological activity. Eur J Immunol 1982; 12:1054-7.

4 Bonney RJ, Naruns P, Davies P, Humes JL. Antigen-antibody complexes stimulate the synthesis and release of prostaglandins by mouse peritoneal macrophages. Prostaglandins 1979; 18:605-16.

5 Rouzer CA, Scott WA, Hamill AL, Liu FT, Katz DH, Cohn ZA. Secretion of leukotriene $\mathrm{C}$ and other arachidonic acid metabolites by macrophages challenged with immunoglobulin E immune complexes. J Exp Med 1982; 156:1077-86.

6 Polat GL, Laufer J, Fabian I, Passwell JH. Cross-linking of monocyte plasma membrane $\mathrm{Fc}$ alpha, $\mathrm{Fc}$ gamma or mannose receptors induces TNF production. Immunology 1993; 80:287-92.

7 Berger S, Balló H, Stutte HJ. Immune complex-induced interleukin-6, interleukin-10 and prostaglandin secretion by human monocytes: a network of pro- and anti-inflammatory cytokines dependent on the antigen: antibody ratio. Eur J Immunol 1996; 26:1297-301.

8 Nitta T, Suzuki T. Biochemical signals transmitted by Fc-gamma receptors: triggering mechanisms of the increased synthesis of adenosine-3', 5'-cyclic monophosphate mediated by Fc-gamma2aand Fc-gamma2b-receptors of a murine macrophage-like cell line (P388D1). J Immunol 1982; 129:2708-14.

9 Ravetch JV, Kinet JP. Fc receptors. Annu Rev Immunol 1991; 9:457-92.

10 Clynes R, Ravetch JV. Cytotoxic antibodies trigger inflammation through Fc receptors. Immunity 1995; 3:21-6.

11 Daëron M. Fc receptor biology. Annu Rev Immunol 1997; 15:203-34.

12 Virgin HW, Wittenberg GF, Unanue ER. Immune complex effects on murine macrophages. I. Immune complexes suppress interferon- $\gamma$ induction of Ia expression. J Immunol 1985; 135:3735-43.

13 Revel M, Chebath J. Interferon-activated genes. Trends Biochem Sci 1986; 11:166-70.

14 Hanaumi K, Gray P, Suzuki T. Fc $\gamma$ receptor-mediated supression of $\gamma$ interferon-induced Ia antigen expression on a murine macrophage-like

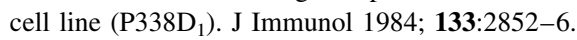

15 Farraf MA, Schreiber RD. The molecular cell biology of interferon- $\gamma$ and its receptor. Annu Rev Immunol 1993; 11:571-611.

16 Rosa FM, Cochet MM, Fellous M. Interferon and major histocompatibility complex genes: a model to analyse eukaryotic gene regulation? Interferon 1986; 7:48-87.

17 Van Weyenbergh J, Lipinski P, Abadie A et al. Antagonistic action of IFN- $\beta$ and IFN- $\gamma$ on high affinity Fc $\gamma$ receptor expression in healthy controls and multiple sclerosis patients. J Immunol 1998; 161:1568-74.

18 Esparza I, Green R, Schreiber RD. Inhibition of macrophage tumoricidal activity by immune complexes and altered erythrocytes. J Immunol 1983; 131:2117-21.

19 Boyum A. Isolation of mononuclear cells and granulocytes from human blood. Isolation of mononuclear cells by one centrifugation, and of granulocytes by combining centrifugation and sedimentation at $1 \mathrm{~g}$. Scand J Clin Lab Invest Suppl 1968; 97:77-89.

20 Balaji KN, Boom WH. Processing of Mycobacterium tuberculosis bacilli by human monocytes for CD4 $+\alpha \beta$ and $\gamma \delta \mathrm{T}$ cells: role of particulate antigen. Infect Immun 1998; 66:98-106.

21 Perussia B, Dayton ET, Lazarus R, Fanning V, Trinchieri G. Immune interferon induces the receptor for monomeric IgG1 on human monocytic and myeloid cells. J Exp Med 1983; 158:1092-113.

22 James F, Brouquisse R, Suire C, Pradet A, Raymond P. Purification and biochemical characterization of a vacuolar serine endopeptidase induced by glucose starvation in maize roots. Biochem J 1996; 320:283-92.

23 Eid M, Evin G, Castro B, Menard J, Corvol P. New renin inhibitors homologous with pepstatin. Biochem J 1981; 197:465-71.

24 Barnes K, Shimada K, Takahashi M, Tanzawa K, Turner AJ. Metallopeptidase inhibitors induce an up-regulation of endothelinconverting enzyme levels and its redistribution from the plasma membrane to an intracellular compartment. J Cell Sci 1996; 109:919-28.

25 Savory PJ, Rivett AJ. Leupeptin-binding site(s) in the mammalian multicatalytic proteinase complex. Biochem J 1993; 289:45-8.

26 Tripp CS, Beckerman KP, Unanue ER. Immune complexes inhibit antimicrobial responses through interleuquin-10 production. Effects in severe combined immunodeficient mice during Listeria infection. J Clin Invest 1995; 95:1628-34.

27 Cresswell P. Antigen presentation. Getting peptides into MHC class II molecules. Curr Biol 1994; 4:541-3.

28 Feldman GM, Chuang EJ, Finbloom DS. IgG immune complexes inhibit IFN- $\gamma$-induced transcription of the Fc $\gamma$ RI gene in human monocytes by preventing the tyrosine phosphorylation of the p91 (Stat1) transcription factor. J Immunol 1995; 154:318-25.

29 Bazil V. Physiological enzymatic cleavage of leukocyte membrane molecules. Immunol Today 1995; 16:135-40.

30 Alves-Rosa MF, Vulcano M, Beigier M, Breyer I, Isturiz MA. The

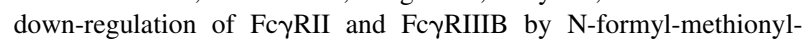
leucyl-phenylalanine (FMLP) depends on secretory events in human neutrophils. Immunol Lett 1999; 70:119-26.

31 Celada A. Immune-complex inhibition of macrophage activation is not due to an interaction with the binding or processing of IFN- $\gamma$. Immunology 1988; 64:187-92.

32 Mui AL, Kay RJ, Humphries RK, Krystal G. Ligand-induced phosphorylation of the murine interleukin 3 receptor signals its cleavage. Proc Natl Acad Sci USA 1992; 89:10812-6.

33 Hintzen RQ, Lens SM, Beckmann MP, Goodwin RG, Lynch D, van Lier RA. Characterization of the human CD27 ligand, a novel member of the TNF gene family. J Immunol 1994; 152:1762-73.

34 Demaria S, Schwab R, Gottesman SR, Bushkin Y. Soluble beta 2microglobulin-free class I heavy chains are released from the surface of activated and leukemia cells by a metalloprotease. J Biol Chem 1994; 269:6689-94. 